\title{
An Innovative Approach Continual Improvement of CO-PO Attainments
}

\author{
M Rajendra Prasad ${ }^{1}$, M N L Anuradha ${ }^{2}$ \\ J.Govardhan Reddy ${ }^{3}$ \\ ${ }^{1}$ ECE, Vidya Jyothi Institute of Technology, Hyderabad \\ ${ }^{2} \mathrm{H} \& S$, Vidya Jyothi Institute of Technology,Hyderabad \\ ${ }^{3}$ H\&S, Vidya Jyothi Institute of Technology,Hyderabad \\ ${ }^{1}$ rajendraresearch@gmail.com \\ 2 anuradha.chennuru@gmail.com \\ ${ }^{3}$ goverdhanreddy.javini@gmail.com
}

\begin{abstract}
With the growing quantity and quality of information on the internet, the trends in teaching have accelerated rapidly in recent years. The teacher's role has changed from that of knowledge-transmitter to consultant, guide, coach, and facilitator. The Outcome Based Education (OBE) Curriculum outlines specific measurable outcomes for each Course. The entire Curriculum focuses on what students can actually do after they complete the Course. In this Curriculum the teacher should focus on helping the students in providing \& developing the knowledge and skills that enable them to achieve the clearly defined outcomes. After the completion of the course, attainment of that particular Course is evaluated .In this paper we talk about an innovative methodology for continuous improvement (IMCI) which is implemented at Vidya Jyothi Institute of Technology, Hyderabad that comprises of some activities which benefit the students to improve their academic performance there by increasing the attainment of that particular course. This increases the CO-PO Attainment values.
\end{abstract}

Keywords: Outcome Based Education (OBE), Course Outcomes, Program Outcomes, Attainment.

\section{Introduction}

Outcome Based Education focuses on Teaching-Learning enhancement in the field of engineering education system all over the globe. The OBE implementation has been supported by most academic institutions, which offers engineering courses in India and abroad.

\section{Corresponding Author}

ECE, Vidya Jyothi Institute of Technology, Hyderabad rajendraresearch@gmail.com
The process of execution of OBE is not an easy task. It requires a lot of effort to design Program Educational Objectives (PEOs) after defining the Vision and Mission of the Department, which are derived from the Institution's Vision, and Mission. Program Outcomes (Pos) are narrower statements that describe what students are expected to know and be able to do after completion of the course or program. The Course Outcomes (COs) are stated in such a way that they can be actually measured. The performance of the students indicates the $\mathrm{CO}$ attainment. This measurement provides the basis for continuous improvement in the quality of learning. In this paper an innovative Methodology for continuous improvement (IMCI) which is designed for all B.Tech I Year courses and implemented successfully that resulted in the improvement of CO-PO Attainments. This paper also describes and analyses the improvement in the CO-PO Attainment values.

\section{Literature Review and Related Work}

Bhimasen Sorian \& K S Mahesh proposes a methodology for Measuring Attainment of Course Outcomes and Program Outcomes [1]. Dr.Rita Jain \& Dr. A. A. Ansari proposed a simplified approach to measure course outcomes and program outcomes [2]. M.Rajendra Prasad implemented project based teaching methodology for embedded engineering education for effective attainment [3]. VA Kulkarni , B. B. Ahuja \&MR Dhanvijay proposed a method for CO-PO Mapping and Attainment calculation[4]. Chandra R. Sekhar, Omer Farook and Essaid Bouktache gave a Continuous Improvement Process Based on Outcome Based Education [5].In this paper a methodology (IMCI) is employed to enhance the academic performance of the students over 5 academic years.

\section{Methodology}

The process of calculation of attainments for COs and POs starts from writing appropriate COs for each course of the program from first year to fourth year in a four-year 
engineering degree program. The course outcomes are written by the respective faculty members using action verbs of Blooms Taxonomy.. Then, a correlation is established between COs and POs in the scale of 1 to 3,1 being the slight (low), 2 being moderate (medium) and 3 being substantial (high). A mapping matrix is prepared in this regard for every course in the program .The course outcomes written and their mapping with POs are reviewed frequently by a committee of senior faculty members before they are finalized. The example of such a mapping for the course Mathematics I is given in table 1.Based on the mapping the CO-PO attainments can be calculated with the help of the procedure described in figure 1.An example of such calculation is given in the table 2 .

The Course Outcomes of Mathematics I

1. Understand the term rank and Elementary Transformations of a Matrix, System of Equations.

2. Compute Eigen values and corresponding Eigen vectors of a square matrix, finding Inverse and method of Diagonalization.

3. Verification of the Mean value theorems and to study maxima and minima of functions of two variables.

4. Evaluation of improper integrals by using beta gamma functions and evaluation of double and triple integrals by tracing the region of integration.

5. Finding Laplace transform of various functions and solving the initial value problems by using Laplace transforms.

According to these Cos the mapping is given in the following table

\section{Table 1: CO-PO mapping of Mathematics I}

\begin{tabular}{|c|c|c|c|c|c|c|c|c|c|c|c|c|}
\hline & $\begin{array}{l}\text { PO } \\
1\end{array}$ & $\begin{array}{l}\mathbf{P} \\
\mathbf{O} \\
2\end{array}$ & $\begin{array}{l}\mathbf{P} \\
\mathbf{O} \\
\mathbf{3}\end{array}$ & $\begin{array}{l}P \\
O \\
4\end{array}$ & $\begin{array}{l}\mathbf{P} \\
\mathbf{O} \\
5\end{array}$ & $\begin{array}{l}\mathbf{P} \\
\mathbf{O} \\
6\end{array}$ & $\begin{array}{l}\mathbf{P} \\
\mathbf{O} \\
7\end{array}$ & $\begin{array}{l}\mathbf{P} \\
\mathbf{O} \\
8\end{array}$ & $\begin{array}{l}\mathbf{P} \\
\mathbf{O} \\
9\end{array}$ & $\begin{array}{l}\mathbf{P} \\
\mathbf{O} \\
\mathbf{1} \\
\mathbf{0}\end{array}$ & $\begin{array}{l}\mathbf{P} \\
\mathbf{O} \\
\mathbf{1} \\
\mathbf{1}\end{array}$ & $\begin{array}{l}\mathbf{P} \\
\mathbf{O} \\
\mathbf{1} \\
\mathbf{2}\end{array}$ \\
\hline CO1 & - & 3 & 3 & 3 & 2 & - & - & 1 & - & 1 & - & - \\
\hline $\mathrm{CO2}$ & 3 & 3 & - & 3 & 3 & 3 & 1 & - & 2 & - & 1 & 3 \\
\hline $\mathrm{CO3}$ & 3 & - & 3 & 3 & - & - & 1 & 1 & 2 & 1 & - & \begin{tabular}{|l|}
3 \\
\end{tabular} \\
\hline $\mathrm{CO4}$ & - & 3 & - & - & 1 & 3 & - & 1 & - & 1 & 1 & 3 \\
\hline CO5 & 3 & - & 3 & - & - & 3 & 1 & - & 2 & - & 1 & - \\
\hline AVG & 3 & 3 & 3 & 3 & 2 & 3 & 1 & 1 & 2 & 1 & 1 & 3 \\
\hline
\end{tabular}

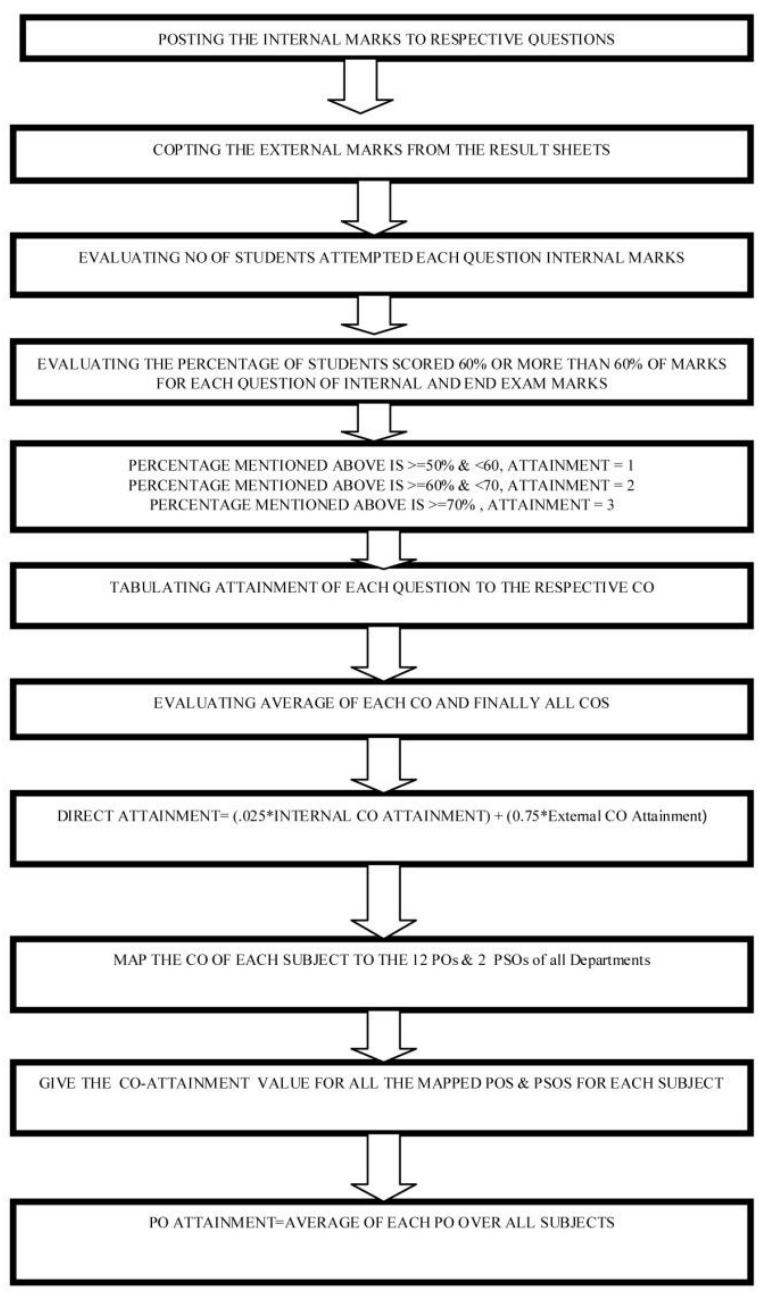

Figure 1: PO Attainment calculation process

Table 2: CO-PO Attainment calculation for B.Tech First Year Courses in one academic year

\begin{tabular}{|c|c|c|c|c|c|c|c|c|c|c|c|c|}
\hline COURSE & $\begin{array}{l}\text { P } \\
\text { O1 }\end{array}$ & $\begin{array}{l}\mathbf{P} \\
\mathrm{O} 2\end{array}$ & $\begin{array}{l}\mathbf{P} \\
\mathbf{O} 3\end{array}$ & $\begin{array}{l}\mathrm{P} \\
\mathrm{O}\end{array}$ & $\begin{array}{l}\mathbf{P} \\
\mathbf{O 5}\end{array}$ & $\begin{array}{l}\mathbf{P} \\
\mathbf{O 6}\end{array}$ & $\begin{array}{l}\text { P } \\
\text { O7 }\end{array}$ & $\begin{array}{l}\text { P } \\
\text { O8 }\end{array}$ & $\begin{array}{l}\mathbf{P} \\
\text { O9 }\end{array}$ & $\begin{array}{l}\text { PO } \\
10\end{array}$ & $\begin{array}{l}\text { PO } \\
11\end{array}$ & $\begin{array}{l}\text { PO } \\
12\end{array}$ \\
\hline ENGLISH & $\begin{array}{l}2.3 \\
3\end{array}$ & - & - & $\begin{array}{l}2.3 \\
3\end{array}$ & - & $\begin{array}{l}2.3 \\
3\end{array}$ & $\begin{array}{l}2.3 \\
3\end{array}$ & $\begin{array}{l}2.3 \\
3\end{array}$ & $\begin{array}{l}2.3 \\
3\end{array}$ & $\begin{array}{l}2.3 \\
3\end{array}$ & - & $\begin{array}{l}2.3 \\
3\end{array}$ \\
\hline $\begin{array}{l}\text { MATHEMAT } \\
\text { ICS I }\end{array}$ & $\begin{array}{l}1.6 \\
2\end{array}$ & $\begin{array}{l}1.6 \\
2\end{array}$ & $\begin{array}{l}1.6 \\
2\end{array}$ & $\begin{array}{l}1.6 \\
2\end{array}$ & $\begin{array}{l}1.6 \\
2\end{array}$ & $\begin{array}{l}1.6 \\
2\end{array}$ & $\begin{array}{l}1.6 \\
2\end{array}$ & $\begin{array}{l}1.6 \\
2\end{array}$ & $\begin{array}{l}1.6 \\
2\end{array}$ & $\begin{array}{l}1.6 \\
2\end{array}$ & $\begin{array}{l}1.6 \\
2\end{array}$ & $\begin{array}{l}1.6 \\
2\end{array}$ \\
\hline $\begin{array}{l}\text { ENGG.PHYSI } \\
\text { CS }\end{array}$ & $\begin{array}{l}1.6 \\
3\end{array}$ & $\begin{array}{l}1.6 \\
3\end{array}$ & $\begin{array}{l}1.6 \\
3\end{array}$ & $\begin{array}{l}1.6 \\
3\end{array}$ & $\begin{array}{l}1.6 \\
3\end{array}$ & $\begin{array}{l}1.6 \\
3\end{array}$ & $\begin{array}{l}1.6 \\
3\end{array}$ & $\begin{array}{l}1.6 \\
3\end{array}$ & $\begin{array}{l}1.6 \\
3\end{array}$ & $\begin{array}{l}1.6 \\
3\end{array}$ & $\begin{array}{l}1.6 \\
3\end{array}$ & $\begin{array}{l}1.6 \\
3\end{array}$ \\
\hline $\begin{array}{l}\text { ENGG.CHEM } \\
\text { ISTRY }\end{array}$ & $\begin{array}{l}1.7 \\
3\end{array}$ & $\begin{array}{l}1.7 \\
3\end{array}$ & $\begin{array}{l}1.7 \\
3\end{array}$ & $\begin{array}{l}1.7 \\
3\end{array}$ & $\begin{array}{l}1.7 \\
3\end{array}$ & $\begin{array}{l}1.7 \\
3\end{array}$ & $\begin{array}{l}1.7 \\
3\end{array}$ & - & - & & $\begin{array}{l}1.7 \\
3\end{array}$ & $\begin{array}{l}1.7 \\
3\end{array}$ \\
\hline CPDS & $\begin{array}{l}1.7 \\
4\end{array}$ & $\begin{array}{l}1.7 \\
4\end{array}$ & $\begin{array}{l}1.7 \\
4\end{array}$ & $\begin{array}{l}1.7 \\
4\end{array}$ & $\begin{array}{l}1.7 \\
4\end{array}$ & $\begin{array}{l}1.7 \\
4\end{array}$ & $\begin{array}{l}1.7 \\
4\end{array}$ & $\begin{array}{l}1.7 \\
4\end{array}$ & $\begin{array}{l}1.7 \\
4\end{array}$ & $\begin{array}{l}1.7 \\
4\end{array}$ & $\begin{array}{l}1.7 \\
4\end{array}$ & $\begin{array}{l}1.7 \\
4\end{array}$ \\
\hline EDRAWING & $\begin{array}{l}1.7 \\
4\end{array}$ & $\begin{array}{l}1.7 \\
4\end{array}$ & $\begin{array}{l}1.7 \\
4\end{array}$ & $\begin{array}{l}1.7 \\
4\end{array}$ & $\begin{array}{l}1.7 \\
4\end{array}$ & $\begin{array}{l}1.7 \\
4\end{array}$ & - & - & $\begin{array}{l}1.7 \\
4\end{array}$ & $\begin{array}{l}1.7 \\
4\end{array}$ & & $\begin{array}{l}1.7 \\
4\end{array}$ \\
\hline $\begin{array}{l}\text { MATHEMAT } \\
\text { ICAL } \\
\text { METHODS }\end{array}$ & $\begin{array}{l}1.4 \\
8\end{array}$ & $\begin{array}{l}1.4 \\
8\end{array}$ & $\begin{array}{l}1.4 \\
8\end{array}$ & $\begin{array}{l}1.4 \\
8\end{array}$ & $\begin{array}{l}1.4 \\
8\end{array}$ & $\begin{array}{l}1.4 \\
8\end{array}$ & $\begin{array}{l}1.4 \\
8\end{array}$ & $\begin{array}{l}1.4 \\
8\end{array}$ & $\begin{array}{l}1.4 \\
8\end{array}$ & - & $\begin{array}{l}1.4 \\
8\end{array}$ & $\begin{array}{l}1.4 \\
8\end{array}$ \\
\hline CPDS LAB & 3 & 3 & 3 & 3 & 3 & 3 & 3 & 3 & 3 & 3 & 3 & 3 \\
\hline EP/EC LAB & 3 & 3 & 3 & 3 & 3 & 3 & 3 & 3 & 3 & 3 & 3 & 3 \\
\hline ELCS LAB & 3 & - & - & 3 & - & 3 & 3 & 3 & 3 & 3 & - & 3 \\
\hline $\begin{array}{l}\text { ITWS/EWS } \\
\text { LAB }\end{array}$ & 3 & 3 & 3 & 3 & 3 & 3 & 3 & 3 & 3 & 3 & - & 3 \\
\hline AVERAGE & $\begin{array}{l}2.2 \\
1\end{array}$ & $\begin{array}{l}2.1 \\
0\end{array}$ & $\begin{array}{l}2.1 \\
0\end{array}$ & $\begin{array}{l}2.2 \\
1\end{array}$ & $\begin{array}{l}2.1 \\
0\end{array}$ & $\begin{array}{l}2.2 \\
1\end{array}$ & $\begin{array}{l}2.2 \\
5\end{array}$ & $\begin{array}{l}2.3 \\
1\end{array}$ & $\begin{array}{l}2.2 \\
5\end{array}$ & $\begin{array}{l}2.3 \\
4\end{array}$ & $\begin{array}{l}2.0 \\
3\end{array}$ & $\begin{array}{l}2.2 \\
1\end{array}$ \\
\hline
\end{tabular}


4. The Remedial Actions taken to improve the performance of the students:

After analyzing the value of CO-PO attainment for the continuous improvement of the first year B.Tech courses the following actions were implemented.
1. Remedial Classes
2. Make-Up Classes
3. Guest Lectures
4. Slip tests
5. Communication and Interpersonal Skills

\subsection{Remedial Classes}

Remedial classes are often used to improve the basics in a subject such as maths, science or languages. These classes can help the students who are having problems with advanced concepts by giving a strong foundation in basics. Students can also use them to catch up on the concepts after a long break from education. The following process is implemented to select the remedial students.

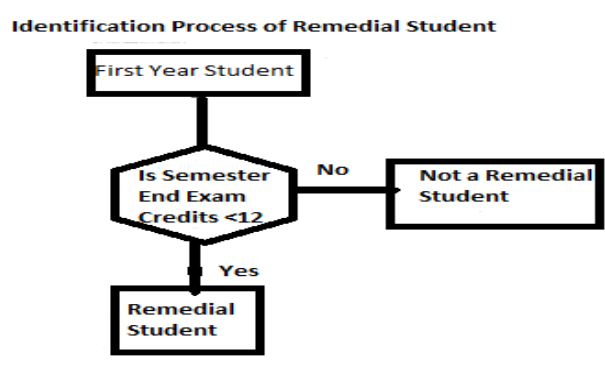

\section{Figure 2: Remedial Classes student selection process}

\subsection{Make up Classes}

Make up Classes are conducted for slow learners after 8 weeks of class work by taking the feedback from the subject teachers. It is proved to be very effective method to improve the slow learners performance.

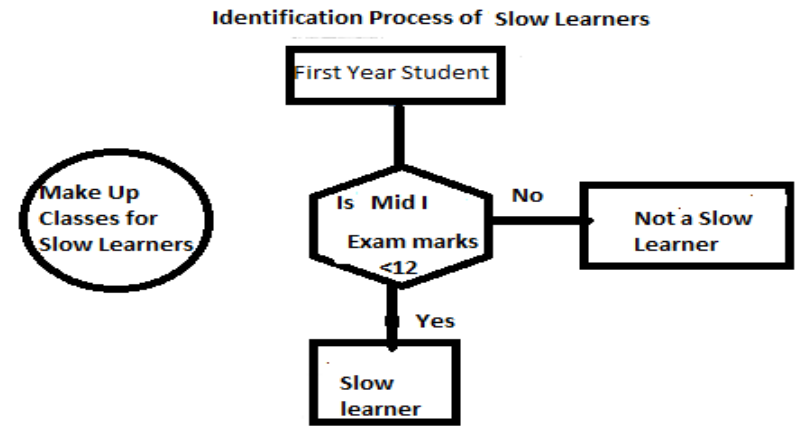

Figure 3: Make up Classes student selection process

\subsection{Guest Lectures}

After making a study on gap analysis and discussion with the faculty members the following Guest Lectures were conducted at Vidya Jyothi Institute of Technology,

Hyderabad.

\section{Table 3: List of Guest Lectures}

After making a study on gap analysis and discussion with the faculty members the following Guest Lectures were conducted at Vidya Jyothi Institute of Technology, Hyderabad.

\begin{tabular}{|c|c|c|c|}
\hline S.No & Subject & Date & Topic \\
\hline 1 & Mathematics & $15-7-2015$ & $\begin{array}{l}\text { Application of } \\
\text { Matrices in Real Life }\end{array}$ \\
\hline 2 & English & $10-8-2015$ & $\begin{array}{l}\text { Improvement in } \\
\text { Teaching Learning } \\
\text { Skills }\end{array}$ \\
\hline 3 & Physics & $21-8-2015$ & $\begin{array}{l}\text { Nano } \\
\text { Photonics or Nano- } \\
\text { Optics }\end{array}$ \\
\hline 4 & Mathematics & $12-01-2016$ & $\begin{array}{l}\text { Role of Mathematics in } \\
\text { Engineering \& } \\
\text { Sciences }\end{array}$ \\
\hline 5 & English & $15-7-2016$ & $\begin{array}{l}\text { Empowering Education } \\
\text { in ELT \& Teaching } \\
\text { Communication Skills }\end{array}$ \\
\hline 6 & Physics & $18-11-2016$ & $\begin{array}{l}\text { Lasers \& Optical } \\
\text { Fibers. }\end{array}$ \\
\hline 7 & Physics & $6-5-2017$ & $\begin{array}{l}\text { Laser Spectroscopy for } \\
\text { Explosives Detection }\end{array}$ \\
\hline 8 & Mathematics & 6-09-2017 & $\begin{array}{lr}\text { Applications } & \text { of } \\
\text { Numerical } & \text { Methods }\end{array}$ \\
\hline 9 & $\begin{array}{c}\text { Computer } \\
\text { Programming }\end{array}$ & 17.02 .2018 & $\begin{array}{l}\text { Introduction to } \\
\text { Computer Applications }\end{array}$ \\
\hline
\end{tabular}


The Subject knowledge of the students increased in that particular area due to the above guest lectures given by experts. This raised the interest of the students to learn the subjects there by increasing the attainment levels.

\subsection{Slip tests}

One of the major component of our education system is examination. The education process in any discipline of learning ends with examinations. The entire effort put in by the teachers on teaching and the student on learning is centered on getting good results in the examinations. Regular Slip tests are conducted in class that helps them to prepare for exams in an easy way. After completion of a concept a small test will be conducted to evaluate the performance of the students.

\subsection{Communication and Interpersonal Skills}

Interpersonal skills are people skills. They're the skills that are used while communicating and collaborating with others, both individually and in groups. Strongly associated with emotional intelligence, interpersonal skills are the attributes that are used to understand what motivates people and how they use their knowledge to achieve the best results in all streams of life. In today's job market, possessing technical skills is not enough. You need to go beyond the call of duty and show that you have what it takes to fit within the organization culture. From career point of view, now-a-days, recruiters use personality tests and assessments and gauge who will be a better fit between two applicants of similar qualifications and experience. They rely on identifying interpersonal skills. Interpersonal skills will give them a chance to differentiate from other job applicants as well as workmates and move up the ladder. These complement their technical skills, enhance the job performance and social interactions.

Implementing the above methodology the student whose result was down the mark have shown a positive remarkable change in their knowledge and retaining capacity. As a result the attainment levels has increased considerably.

\section{Result Analysis}

The CO-PO attainment values of I B.Tech courses for 5 consecutive years are analyzed for 5 Programs and are described below.

\section{Table 4 : PO 1(Engineering Knowledge)}

It is observed that MECH,EEE Programs have improved much with respected to this PO 1.

\begin{tabular}{|l|r|r|r|r|r|}
\hline & \multicolumn{1}{l|l}{$\begin{array}{l}\text { 2013- } \\
\text { 14 }\end{array}$} & \multicolumn{1}{l|}{$\begin{array}{l}\text { 15 } \\
\text { 15- }\end{array}$} & $\begin{array}{l}\text { 2015- } \\
\text { 16 }\end{array}$ & $\begin{array}{l}\text { 2016- } \\
\text { 17 }\end{array}$ & 2017-18 \\
\hline EEE & 2.18 & 2.2 & 2.32 & 2.45 & 2.58 \\
\hline MECH & 1.5 & 1.65 & 1.7 & 1.85 & 2 \\
\hline ECE & 2.22 & 2.35 & 2.42 & 1.25 & 2.65 \\
\hline CSE & 2.11 & 2.22 & 2.34 & 2.45 & 2.57 \\
\hline IT & 2.16 & 2.25 & 2.32 & 2.41 & 2.57 \\
\hline
\end{tabular}

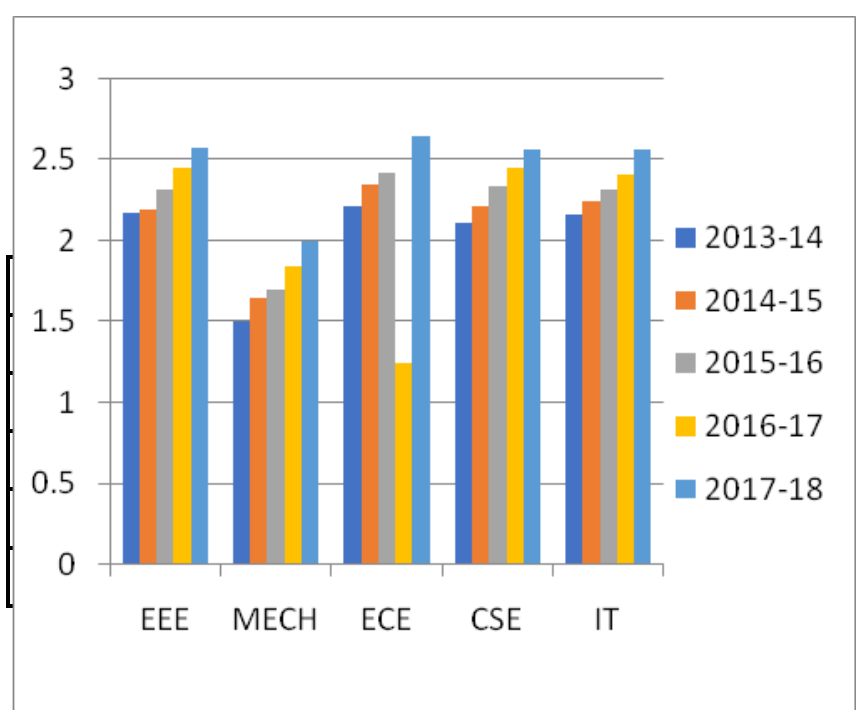

Table 5 : PO 2(Problem Analysis)

It is observed that All Programs have improved much with respected to this PO 2.

\begin{tabular}{|c|c|c|c|c|c|}
\hline & $\begin{array}{l}2013- \\
14\end{array}$ & $\begin{array}{l}\text { 2014- } \\
15\end{array}$ & $\begin{array}{l}2015- \\
16\end{array}$ & $\begin{array}{l}\text { 2016- } \\
17\end{array}$ & 2017-18 \\
\hline EEE & 2.06 & 2.12 & 2.22 & 2.35 & 2.45 \\
\hline МECH & 1.21 & 1.31 & 1.45 & 1.54 & 1.62 \\
\hline ECE & 2.13 & 2.22 & 2.35 & 2.48 & 2.59 \\
\hline CSE & 2.01 & 2.14 & 2.27 & 2.38 & 2.54 \\
\hline IT & 1.99 & 2.11 & 2.22 & 2.38 & 2.49 \\
\hline
\end{tabular}

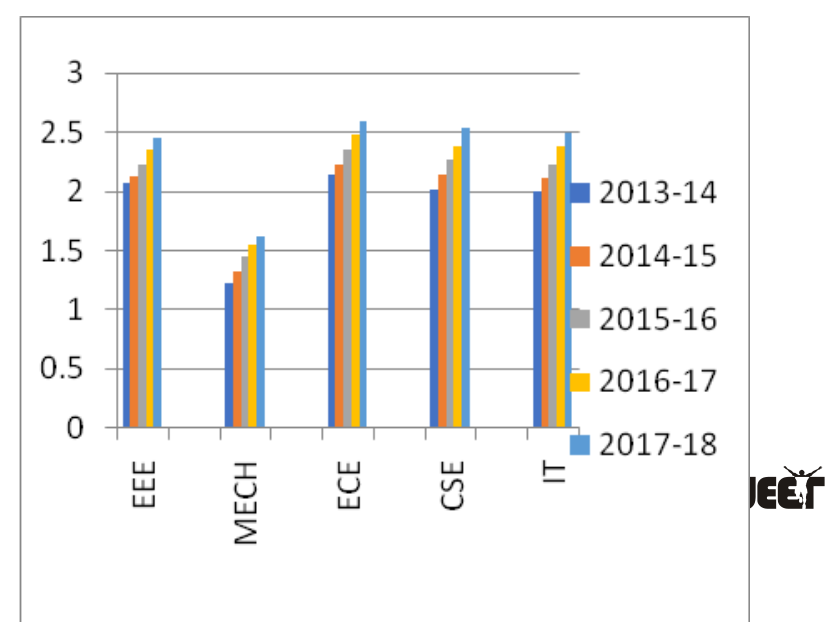


Table 6: PO3 (Design/Development of solutions) It is observed that CSE,ECE Programs have improved much with respected to this PO 3.

\begin{tabular}{|l|r|r|r|r|r|}
\hline & \multicolumn{2}{|c|}{$\mathbf{2 0 1 3 - 1 4}$} & $\mathbf{2 0 1 4 - 1 5}$ & $\mathbf{2 0 1 5 - 1 6}$ & \multicolumn{2}{|c|}{ 2016-17 } & \multicolumn{1}{c|}{$\begin{array}{c}\text { 2017- } \\
\mathbf{1 8}\end{array}$} \\
\hline EEE & 2.06 & 2.18 & 2.29 & 2.33 & 2.45 \\
\hline MECH & 1.03 & 1.15 & 1.28 & 1.37 & 1.55 \\
\hline ECE & 1.99 & 2.11 & 2.25 & 2.33 & 2.48 \\
\hline CSE & 2.01 & 2.14 & 2.22 & 2.35 & 2.58 \\
\hline IT & 1.99 & 2.21 & 2.29 & 2.35 & 2.47 \\
\hline
\end{tabular}

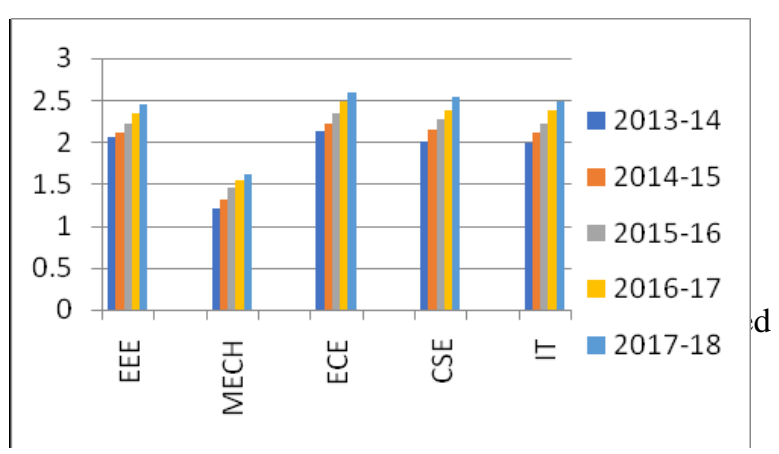

Table 7: PO10(Communication)

It is observed that CSE,ECE Programs have improved much with respected to this PO 3.

\begin{tabular}{|l|r|r|r|r|r|}
\hline & $\mathbf{2 0 1 3 - 1 4}$ & $\mathbf{2 0 1 4 - 1 5}$ & $\mathbf{2 0 1 5 - 1 6}$ & $\mathbf{2 0 1 6 - 1 7}$ & $\mathbf{2 0 1 7 - 1 8}$ \\
\hline EEE & 2.11 & 2.22 & 2.34 & 2.48 & 2.61 \\
\hline MECH & 0.64 & 1.11 & 1.26 & 1.32 & 1.45 \\
\hline ECE & 2.01 & 2.11 & 2.23 & 2.33 & 2.48 \\
\hline CSE & 2.04 & 2.22 & 2.31 & 2.41 & 2.54 \\
\hline IT & 2.05 & 2.14 & 2.26 & 2.34 & 2.54 \\
\hline
\end{tabular}

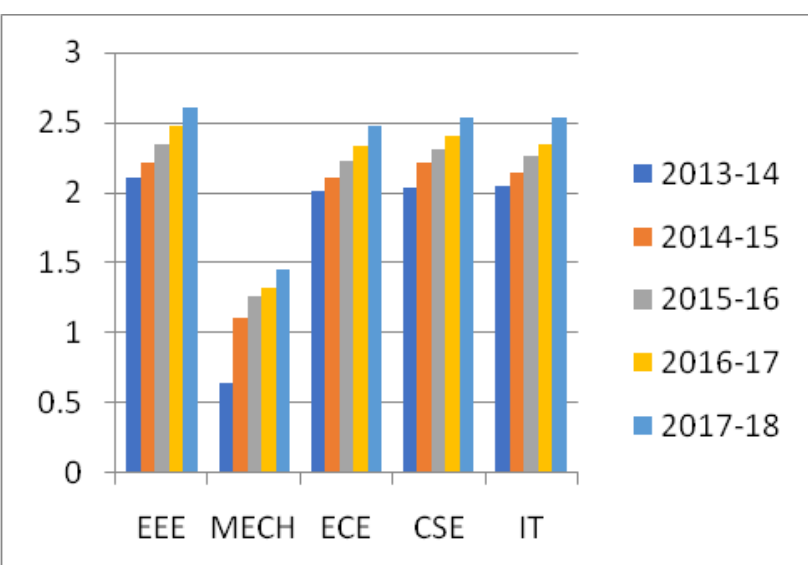

\section{Conclusion}

This paper describes an innovative methodology which is successfully implemented in all Engineering Departments at Vidya Jyothi Institute of Technology, Hyderabad, for various courses and the results of CO-PO Attainments are compared over a period of 5 years. The graphs which are drawn show the growth in the performance.

\section{Acknowledgement}

We would like to thank all faculty members for their continuous support for implementation of $\mathrm{OBE}$ and evaluating the attainment values of various courses at Vidya Jyothi Institute of Technology, Hyderabad. We would like to thank Correspondent, Director and Principal of Vidya Jyothi Institute of Technology, Hyderabad for their encouragement to implement OBE framework.

\section{References}

1. Bhimasen Soragaon \& K S Mahesh, Measuring Attainment of Course Outcomes and Program Outcomes A Simplified Approach as per Self-Assessment Report" IOSR Journal of Research \& Method in Education (IOSRJRME) -June 2015.

2. Dr.Rita Jain1 \& Dr. A. A. Ansari "A Simplified approach to measure course outcomes and program outcomes for accreditation of Engineering Institutes" $2^{\text {nd }}$ International Conference on Emerging Trends in Engineering,Technology,Science \&Management-May 2017.

3. M Rajendra Prasad, D Krishna Reddy, Computer Based Teaching Methodology for Outcome-Based Engineering Education, 6th IEEE International Conference in Advanced Computing(IACC-IEEE Xplore), 2016.

4. Rubýn Sýnchez-Dams, Barýn-Salazar, Marýa Clara Gýmez-ýlvarez, "An Extension of the SEMAT Kernel for Representing Teaching and LearningPracticesaboutEmbeddedSystems",4th

International Conference in Software Engineering Research and Innovation (CONISOFT-IEEE Xplore),2016.

5. GaryK.W.Wong, H.Y.Cheung",Outcome-Based Teaching and Learning in Computer Science Education at Sub-degree Level" International Journal of Information and Education Technology, Vol.1,No.1,April2011.

6. National Board of Accreditation Self-Assessment Report (SAR) For Engineering Programs of Tier - II Institutions - First Time Accreditation, June 2015, available at http://www.nbaind.org/En/1079-selfassessment-report-tier-ii.aspx.

7. Evaluation guidelines by NBA, available at http://www.nbaind.org/files/evaluation-guidelines-tier-iiv0.pdf

8. Anderson, L. W., and Krathwohl, D. R. (2001). Taxonomy for learning, teaching, and assessing, Abridged Edition. Boston, MA: Allyn and Bacon. 
9. Accreditation Manual for UG Engineering Programmes (Tier-II), available at http://www.nbaind.org/Files/NBA\%20\%20Tier\%20II\%20 Manual.pdf.

10. Bhimasen Soragaon1, K. S. Mahesh, Measuring Attainment of Course Outcomes and Program Outcomes A Simplified Approach as per Self-Assessment Report June 2015, IOSR Journal of Research \& Method in Education (IOSR-JRME) e-ISSN: 2320-7388,p-ISSN: 2320-737X Volume 6, Issue 4 Ver. IV (Jul. - Aug. 2016), PP 13-18 www.iosrjournals.org DOI: 10.9790/73880604041318 www.iosrjournals.org.

11. Sunil Magan More et al, Measurement of Course Outcomes Attainment Level for Subject by using Direct Indirect Method, Imperial Journal of Interdisciplinary Research (IJIR) Vol-2, Issue-9, 2016 ISSN: 24541362, http://www.onlinejournal.in Imperial Journal of Interdisciplinary Research (IJIR) Page 1483 - 1487

12. Surendar Rawat, Shruti Karkare, an empirical study on assessment of po attainment for a diploma program, International Journal of Advanced Research in Engineering and Technology (IJARET) Volume 6, Issue 11, Nov 2015, pp. 50-58, Article ID: IJARET_06_11_005, 13. Therese Yamuna Mahesh, Dr. K.L. Shunmuganathan, Measurement of Program Outcomes Attainment for Engineering Graduates by using Neural Networks, International Journal in Engineering and Technology (IJET), Vol 5, Issue 2, ISSN : 2319-1058, pg. 364-369.

14. Chandra R. Sekhar, Omer Farook and Essaid Bouktache, Continuous Improvement Process Based on Outcome Based Education.

15. VA Kulkarni , B. B. Ahuja, MR Dhanvijay, COPO Mapping and Attainment Booklet for Tier-II students with Rubrics Assessment.

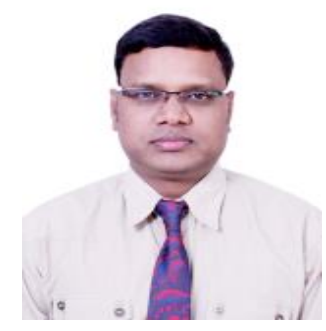

\section{M.Rajendra Prasad}

Obtained his B.E and M.E Electronics and Communication Engineering from SK university and Osmania University respectively. He has 18 years of experience in embedded and telecom research and development. He is submitting Ph.D thesis on Investigations on system level performance of embedded systems for telecom applications. He is currently working as Associate Professor, ECE Department, Vidya Jyothi Insitute of Technology, Hyderabad. He has authored several research and technical papers in engineering education in International magazines and had more papers in Internatinational Journals and Explore . His main research interests are low power embedded system design, wireless protocols, RTOS and Engineering Education. He is also a member of IEEE.

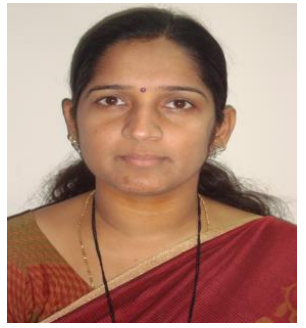

Ms.M.N.L.Anuradha,

Received Post graduate Degree in Mathematics from Osmania University, M.Phil (Mathematics ) from Madurai Kamaraj University and MTech (Computer Science \& Technology) from JNTUH and currently pursuing Ph.D(Mathematics) from KL University. She is having19 years of Teaching Experience and currently working as an Associate Professor in Department of Mathematics at Vidya Jyothi Institute of Technology, Hyderabad. She has published nearly10 publications in the areas of Database, Data Mining, Cloud Computing and Network Security. She is associated with various Professional bodies like ISTE, IA Engg, IACSIT, and CSTA.

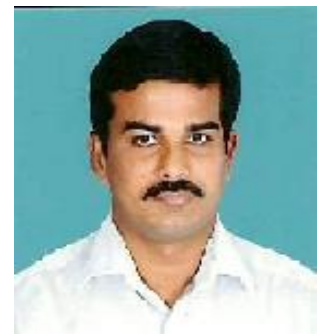

Mr.J.Govardhan Reddy
Received Post graduate
Degree in Mathematics from
Osmania University and
currently pursuing Ph.D
(Mathematics) rrom
Osmania University, Hyderabad. He is having 20 years of Teaching Experience and currently working as an Associate Professor in Department of Mathematics at Vidya Jyothi Institute of Technology, Hyderabad. He has published 3 publications in the area of Mathematical Modeling. 